岡山県のモモにおけるクワオオハダニとミカンハダニの

発生分布之薬剤感受性

\title{
Distribution and Susceptibilities to Acaricides of the Two \\ Closely Related Mites, Panonychus mori Yokoyama and \\ $P$. citri (McGregor), on Peach in Okayama Prefecture, Japan.
}

\author{
藤本博明 ${ }^{1) *}$. 平松高明 ${ }^{2}$ \\ FUJIMOTO, H. ${ }^{1)} *$. T. HIRAMATSU ${ }^{2)}$ \\ 1) 住友化学工業株式会社農業化学品研究所（广605 兵庫県宝塚市高司 4-2-1） \\ Agricultural Chemicals Research Laboratory, Sumitomo Chemical Co., Ltd., \\ Takarazuka, Hyogo, 665 Japan \\ 2) 岡山県立農業試験場（产709-08 岡山県赤磐郡山陽町神田字沖 1174-1） \\ Okayama Prefectural Agricultural Experiment Station, San'yo-cho, \\ Okayama, 709-08 Japan
}

（受領：1995 年 6 月 28 日；登載決定：1995 年 9 月 6 日）

\begin{abstract}
Fujimoto, H. and T. Hiramatsu, 1995. Distributions and susceptibilities to acaricides of the two closely related mites, Panonychus mori Yokoyama and P. citri (McGregor), on peach in Okayama Prefecture, Japan. J. Acarol. Soc. Jpn., 4(2): 103-111.
\end{abstract}

The distributions of Panonychus mori and P. citri occurring on peach in Okayama Prefecture, Japan were investigated. Their susceptibilities to acaricides were also studied for individual populations. Both species were distributed widely on peach trees, and the areas where the distributions of the two species overlapped ranged from intermediate to southern Okayama. The occurrence of each species was consistent in each peach orchard in the areas, and the densities of diapausing eggs of $P$. mori tended to be lower in orchards where the density of adults of $P$. citri were higher. All populations of $P$. mori were susceptible to all acaricides tested, whereas several populations of $P$. citri exhibited extremely low susceptibilities, in particular, to hexythiazox and fenbutatin-oxide.

Key words: Panonychus mori, Panonychus citri, distribution, susceptibility, acaricide, peach

緒言

クワオオハダニ Panonychus mori Yokoyama とミカンハダニ P. citri (McGregor) は, Ehara and Gotoh (1992) によって別種とされるまでそれぞれミカンハダニ休眠系統および

* 現在 住友化学工業株式会社アグロ事業部（テ104 東京都中央区新川 2-27-1）

Present address: Plant Protection Division-Domestic, Sumitomo Chemical Co., Ltd., Chuo-ku, Tokyo, 104 Japan 
非休眠系統と呼ばれていた近縁種である。クワオオ八ダニはナシやモモなどの落葉果樹に発 生し，枝上に休眠卵で越冬する。一方，ミカン八ダニはカンキッ類やイヌッゲなどの常緑樹 で周年発生するほか，越冬はできないむののナシやモモなどの落葉果樹においても発生する (Takafuji and Morimoto, 1983; Takafuji and Fujimoto, 1986; 孫ら，1988; 国本ら，1993)。 両種の落葉果樹における地理的分布は，主要果樹の枝梢上に産卵された卵の休眠性を調べる ことによって明らかにされている（真梶，1961; Shinkaji, 1979)。これによれば，ナシ，モモ などの落葉果樹では概ね瀬戸内から関東南部の太平洋沿岸を境に, クワオオ八ダニがそれよ り北に，ミカン八ダニが南に分布しているとされている。しかしその後の調査によって，そ の境界線近傍にあるナシでは晚夏から秋にかけて両種が混在することが報告されている (Takafuji and Morimoto, 1983; 真梶ら，1986)。また，両種混在地域では，限られた地域内 においても園ごとに両種の発生比率が大きく異なったり（Takafuji and Morimoto, 1983; 真梶ら，1986；孫ら，1988），同一園においても年によって両種の優占度合が大きく変化する （山田ら，1985；真梶ら，1986）など，両種の発生が不安定であることが示唆されている。し かしながら，これまで両種が同一種とみなされていたことああって，両種混在地域での発生 状況を調べた野外調查は, 両種の発生実態および発生に影響を与える要因を十分に解明して はいないと考えられる。

また，両種が寄生する落葉果樹では，諸害虫防除のために薬剤が散布されるのが普通であ り，それは両種の発生に重要な影響を与えていると考えられる。近縁な種とはいえ，両種間 には代謝能力など生理的な相違点が存在する（刑部，1985; Osakabe, 1987)。さらに, 両種が 落葉果樹での発生経過を異にしていること，すなわちクワオオ八ダニが個体群を周年維持す るのに対しミカン八ダニが他の寄主からの移動により個体群を一時的に発生させることから 考えると, 薬剤散布による淘汰の受け方は両種間でかなり異なると予想される。従って, 両 種それぞれの薬剤感受性を知ることは, 両種の落葉果樹における発生と薬剤散布との関係, および落葉果樹に侵入してくるミカン八ダニの発生源を考える上で重要な手掛かりになると 考えられる。しかしながら，ミカンに寄生するミカン八ダニの薬剤感受性についてはこれま で多くの報告があるが（例えば, 岩田ほか, 1984), 落葉果樹に発生する両種の薬剤感受性に ついては，これまで種を区別して得られたデータが殆どない。

そこで本研究では, 両種混在地域における発生実態を明らかにするために, かつて Takafuji and Morimoto (1983) によってナシでの両種の混在が認められた岡山県において，モモ での発生状況を 3 年間にわたり調べた。併せて, 各地から得られた両種それぞれの個体群に ついて主要殺ダ二䫽に対する感受性を調べた。

本文に入るに先立ち, 本研究を進めるにあたり多くのご助言をいただいた住友化学工業(㑣) 笠松紀美博士, ならびに本稿の校閲を賜り貴重なご意見をいただいた京都大学農学研究科高 藤晃雄教授に深謝の意を表する。また, 本調査を行うにあたり, 便宜を図って頂いた栽培農 家の方々に厚くお礼申し上げる。

\section{調查地㧍よび方法}

調査は岡山県下の主要なモモ栽培地域に存在する経済栽培を営むモモ園を中心に行った。 ただし, 山陽町神田の 2 園 (KD-1, KD-2) と久米町宮部 (MB) の園は岡山県立農業試験場 内の試験圃場である。また，モモ園の他に岡山市西隆寺（SR）のナシ園む調査園として加え た。調查はいずれも，およそ $10 \mathrm{a} \cdot 20$ 樹以上の規模で同一の所有者によって栽培管理されて いる成樹園で実施した。 
1. 発生分布調査

発生調查は, 1992 年の秋から 1994 年の夏にかけて雌成虫と休眠卵を対象にそれぞれ年 1 回実施した。雌成虫の調査は，クワオオ八ダニとミカン八ダニの密度がナシにおいて高まる (Takafuji and Morimoto, 1983; Takafuji and Fujimoto, 1986; 孫ら, 1988) とされる 8〜 10 月に行った。著者ら 2 名が各調査園に入り, 約 30 分間それぞれおよそ 10 樹を観察し, Panonychus 属の雌成虫の発生密度を調べるとともに雌成虫が寄生する葉をサンプリングし た。発生密度は以下の基準で 5 段階に分けて記録した。

卅：ほぼ全樹に寄生が認められ，かつ高密度である

世：ほぼ全樹に寄生が認められるが，高密度ではない

H: 半数程度の樹に寄生が認められる

+ ：一部の樹にのみ寄生が認められる

一: いずれの樹にも寄生が認められない

休眠卵の調查は，3〜4 月の孵化直前の時期に行った。雌成虫之同様の方法で各樹の枝梢部 を観察し，同様の基準で発生密度を記録した。なお休眠卵には，クワオオ八ダニとリンゴ八 ダニの 2 種が含まれる可能性があるが， ミカンハダニの非休眠卵はこの時期にはすでに孵化 が完了している（Takafuji and Fujimoto, 1986）ので含まれることはない。各調查園に扔け る調查対象樹はいずれの調查時においても同一とした。

\section{2. 薬剤感受性の検定}

両種のいずれの個体群においても, 野外から多数の雌成虫が得られた場合にはその雌成虫 を実験に用いたが，採集個体数が少ない場合にはモモのリーフディスクで 1〜2 世代増殖さ せた後に実験に用いた。ただし，クワオオ八ダニにおいては，野外から採集した休眠卵から 数世代増殖させた個体群を実験に用いる場合があった。野外からの採集個体数が 30 個体以 下であった場合には，その個体群を用いての検定は実施しなかった。

検定に用いた薬剤は dicofol, hexythiazox, pyridaben, fenbutatin-oxide の 4 種の殺ダニ 剂および殺ダ二活性を有する合成ピレスロイド系殺虫剤 fenpropathrinの 5 薬剤で, いずれ あ市販品を用いた。これらの薬剤はいずれもモモにおける害虫防除剤として岡山県下で広く 使用されている薬剤である。作用特性が薬剂間で異なるが, 同一方法で試験できるように殺 卵活性と殺幼虫活性を併せて検定することとした。水で湿らせた脱脂綿上にモモ葉片（2×2 $\mathrm{cm}$ ）を葉表を上にして置き，これに雌成虫を 4 ～頭接種して $25^{\circ} \mathrm{Cで} 2$ 日間産卵させた。雌 成虫を除去した後, 卵の産下された葉片を松永・古橋 (1972) の方法に準じ $0.5 \%$ の寒天を注 いだポリエチレンカップ $(\phi 7 \mathrm{~cm})$ に設置した。これに対し, 所定の濃度に調製した薬剤稀釈 液を農薬散布器 (大起理化製) を用いて $1 \mathrm{~cm}^{2}$ あたり $3.5 \mathrm{mg}$ の付着量になるように圧力調製 して噴霧した。処理後 $25^{\circ} \mathrm{C}, 50 \%$ R.H. の室内に保持し，8～10 日後に卵の孵化および幼虫の 生死を判定した。幼虫の生死は第 1 若虫に発育した個体を生と扱うことにより行った。薬剤 の供試濃度はモモにおける実用濃度とその $1 / 3$ および $1 / 9$ 濃度の 3 段階をとり, 反復は 1 濃 度につき 4〜 5 とした。供試した卵の総数は, 1 濃度につき通常 100〜200 卵, 少ない場合でも 50 卵以上となるようにした。結果は卵期および幼虫期で死亡した個体を併せて死亡率を求 め，それを無処理区の死亡率で補正することにより表した。 
Table 1. The occurrence of two species of Panonychus on peach in Okayama Prefecture

\begin{tabular}{|c|c|c|c|c|c|c|}
\hline \multirow{3}{*}{$\begin{array}{l}\text { Popul- } \\
\text { ation }\end{array}$} & \multirow{3}{*}{ Locality } & \multicolumn{5}{|c|}{ Mite density ${ }^{\mathrm{a}}$} \\
\hline & & \multicolumn{2}{|c|}{ Diapausing eggs ${ }^{\mathrm{b}}$} & \multicolumn{3}{|c|}{ Adult females ${ }^{c}$} \\
\hline & & 1993 & 1994 & 1992 & 1993 & 1994 \\
\hline IS-1 & Ishu, Syou-oh-cho & H & + & & - & - \\
\hline IS-2 & Ishu, Syou-oh-cho & + & - & & & + \\
\hline $\mathrm{UT}-1$ & Uetsuki, Syou-oh-cho & & m & & & H \\
\hline $\mathrm{UT}-2$ & Uetsuki, Syou-oh-cho & & 世 & & & H \\
\hline SI-1 & Soi, Syou-oh-cho & - & - & & + & - \\
\hline SI-2 & Soi, Syou-oh-cho & + & + & & H & + \\
\hline SI-3 & Soi, Syou-oh-cho & & + & & & + \\
\hline $\mathrm{MB}$ & Miyabe, Kume-cho & H & & & H & \\
\hline $\mathrm{KM}$ & Kusama, niimi-city & m & & & + & \\
\hline $\mathrm{KD}-1$ & Koda, San'yo-cho & m & mt & 曲 & m & - \\
\hline $\mathrm{KD}-2$ & Koda, San'yo-cho & H & H & m & H & + \\
\hline $\mathrm{KD}-3$ & Koda, San'yo-cho & - & + & m & H & - \\
\hline $\mathrm{NN}-1$ & Nishinaka, San'yo-cho & & - & & & - \\
\hline $\mathrm{NN}-2$ & Nishinaka, San'yo-cho & & - & & & - \\
\hline $\mathrm{NN}-3$ & Nishinaka, San'yo-cho & & 世 & & & - \\
\hline $\mathrm{KS}-1$ & Kamosaki, San'yo-cho & & H & & & + \\
\hline $\mathrm{KS}-2$ & Kamosaki, San'yo-cho & & - & & & - \\
\hline HG-1 & Haga, Okayama-city & m & H & + & 世 & - \\
\hline HG-2 & Haga, Okayama-city & - & + & H & - & - \\
\hline HG-3 & Haga, Okayama-city & m & H & m & + & - \\
\hline $\mathrm{HG}-4$ & Haga, Okayama-city & m & m & m & m & H \\
\hline HG-5 & Haga, Okayama-city & & m & & & - \\
\hline HG-6 & Haga, Okayama-city & & - & & + & - \\
\hline HY & Higashiyama, Okayama-city & - & + & + & H & H \\
\hline NG & Nogami, Ihara-city & & & H & & \\
\hline MG-1 & Michiguchi, Kurasiki-city & + & - & H & 曲 & - \\
\hline MG-2 & Michiguchi, Kurasiki-city & - & - & $m$ & H & H \\
\hline MG-3 & Michiguchi, Kurasiki-city & - & - & m & H & - \\
\hline $\mathrm{MG}-4$ & Michiguchi, Kurasiki-city & - & - & H & H & - \\
\hline OY & Ohyabu, Tamano-city & - & & + & m & \\
\hline $\mathrm{SR}$ & $\begin{array}{l}\text { Sairyuji, Okayama-city } \\
\text { (Japanese pear) }\end{array}$ & m & & $m$ & 曲 & \\
\hline
\end{tabular}

${ }^{\text {a }}$ : H : very high, $\mathrm{H}$ : high, $\#$ :medium, + : low, - : no mite. See text for details.

b: Surveys were made in March-April of 1993 and 1994. Densities were based on total abundance of $P$. mori and $P$. ulmi.

c: Surveys were made in September-October of 1992 and in August of 1993 and 1994. Densities were based on total abundance of P. citri, P. mori and P. ulmi. 


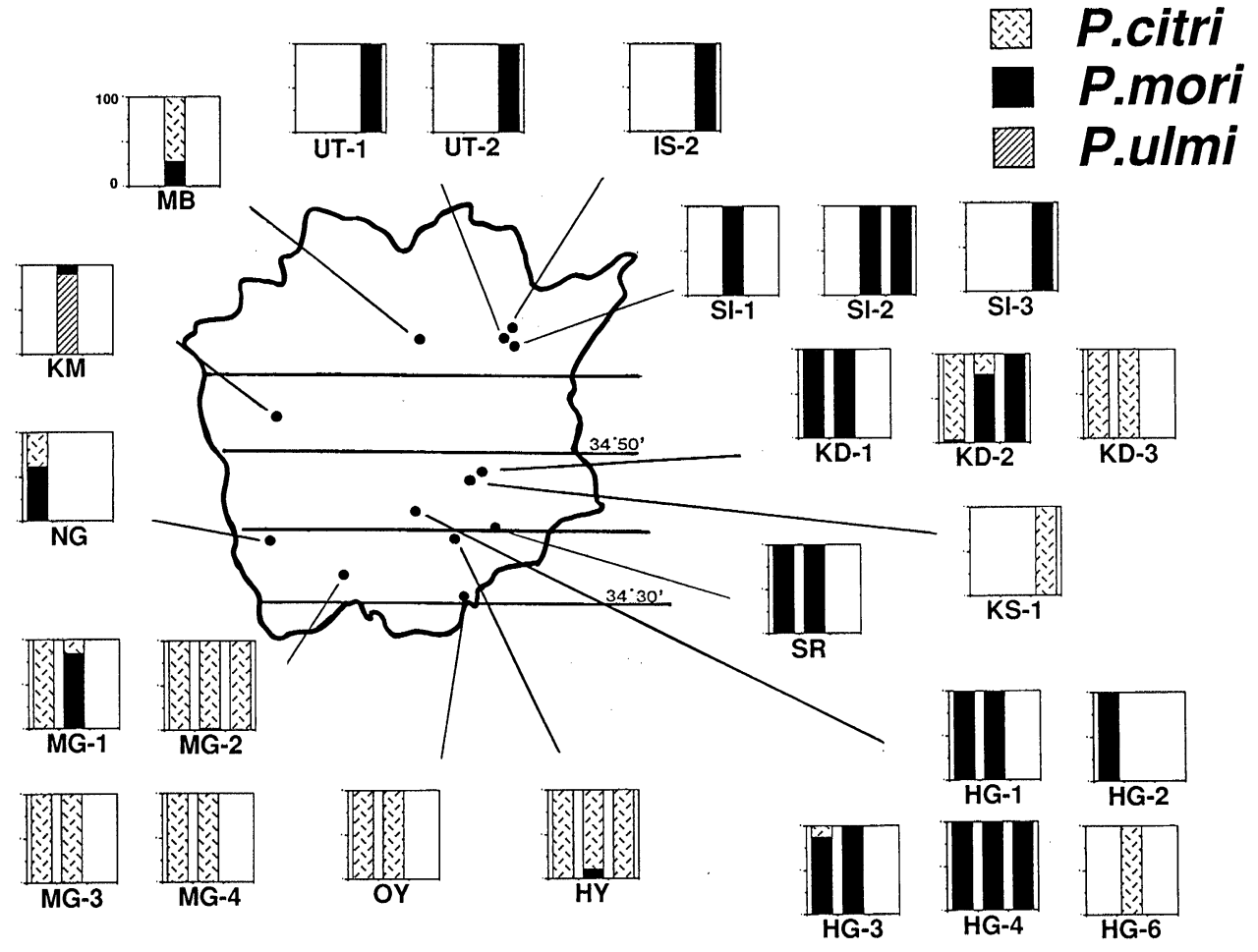

Fig. 1 Distribution of three species of Panonychus on peach in Okayama Prefecture. Each bar shows the proportion of the abundance (adult females) of each species in 1992 (left), 1993 (middle) and 1994 (right). See Table 1 for abbreviated population names.

結 果

\section{1. 発生分布}

発生分布調査の結果を, 休眠卵之雌成虫の発生密度（Table 1) および各種雌成虫の発生比 率. (Table 1 および Fig. 1) によって示した。各調查地から採集した休眠卵を成虫にまで発育 させたところ, リンゴハダニは高標高地 (約 $400 \mathrm{~m}$ ) に位置する草間 (KM) でしか得られず, その他の園ではクワオオ八ダニが得られた。従って, Table 1 の草間 (KM) 以外から採集さ れた休眠卵はすべてクワオオ八ダニである。クワオオ八ダニとミカンハダニの発生分布をま ず地域別にみると, 西隆寺のナシを除く 13 地域のうち, クワオオ八ダニは最南に位置する大 薮 (OY) を除く 12 地域で, ミカン八ダ二は石生 (IS), 植月 (UT), 草間 (KM), 西中 (NN) を除いた 9 地域において発生が認められた。また, 両種の優占度をみると, より南の地域で ミカン八ダニの発生頻度が高い傾向が認められた。以上の結果から, クワオオ八ダニとミカ ン八ダニの両種が岡山県下のモモに広く分布し, 両種の混在地域が比較的広い範囲に及んで いることが明らかになった。

次に, 各調查園における両種の発生推移を雌成虫でみると, 発生量に年次変動があるあの の, 発生する種は殆どの園で一定であった。また, 各調査園におけるクワオオ八ダニの休眠 卵量は, 年次変動が少なく概ね安定していた。しかし, 複数の調査園を含む同一地域内にお いても, 両種の発生状況が園ごとに大きく異なる場合むあった。たとえば山陽町神田では, 
調査園が互いに極めて近接している（直線距離で $600 \mathrm{~m}$ 以内）にむかかわらず， 2 年間にわ たり休眠卵が高密度で認められた園（KD-1）とほとんど認められない園（KD-3）があった。 これらの結果から, クワオオ八ダニとミカンハダニの各調査園における発生量は, 調查園ご との状況にかなり依存している傾向にあると考えられた。

さらにクワオオ八ダニの休眠卵量とミカンハダニの発生との関係を調査園間で比較すると, MB, KD-3, HG-6, HY, MG-1, MG-2, MG-3, MG-4, OY のように，ミカンハダニの発生が認め られた園ではクワオオ八ダ二の休眠卵量が少ない傾向が認められた。この傾向は，岡山市芳賀 や山陽町神田のように複数の調査園を含む同一地域内においても同様に認められた。

\section{2. 薬剤感受性}

Table 2 および 3 にクワオオ八ダニとミカンハダニ各個体群の薬剤感受性を種別にまとめ て示した。モモ寄生のクワオオ八ダニはいずれの個体群も各薬剤に対して高い感受性を示 し, 感受性低下はほとんど認められなかった。しかしながら，ナシ寄生の岡山市西隆寺 (SR) 個体群においては hexythiazox に対する感受性低下が認められた。一方, ミカン八ダニは, fenpropathrin と pyridaben に対してはいずれの個体群も高い感受性を示したが, 他の 3 薬 剤に対しては多くの個体群において顕著な感受性低下が認められ，特に hexythiazox およ び fenbutatin-oxideに対しては複数の個体群において顕著な感受性低下が認められた。 hexythiazoxについては 11 個体群において感受性を検定したが， そのうち KD-3， KS-1,

Table 2. Susceptibility of P.mori populations to five acaricides.

\begin{tabular}{|c|c|c|c|c|c|c|c|c|c|c|}
\hline \multirow{3}{*}{ Acaricides } & \multirow{3}{*}{ Dilution } & \multicolumn{9}{|c|}{ Ovo-larvicidal activity $(\%)^{\mathrm{a}}$} \\
\hline & & \multicolumn{8}{|c|}{ Populations $^{\mathrm{b}}$ on peach } & \multirow{2}{*}{$\frac{\text { on pear }}{\mathrm{SR}}$} \\
\hline & & $\mathrm{UT}-2$ & SI-2 & SI-3 & $\mathrm{KD}-1$ & $\mathrm{KD}-2$ & HG-1 & $\mathrm{HG}-4$ & MG-1 & \\
\hline \multirow{3}{*}{$\begin{array}{l}\text { dicofol } \\
40 \% \text { EC }\end{array}$} & 9,000 & 98.3 & 96.0 & - & - & 2.1 & - & 71.5 & 59.4 & - \\
\hline & 3,000 & 100 & 100 & - & 100 & 38.6 & 95.7 & 100 & 100 & 56.3 \\
\hline & 1,000 & 100 & 100 & 100 & 100 & 98.9 & 100 & 100 & 100 & 95.5 \\
\hline \multirow{3}{*}{$\begin{array}{l}\text { hexythiazox } \\
10 \% \text { WP }\end{array}$} & 18,000 & 100 & 95.1 & - & - & 72.3 & - & 93.2 & 100 & - \\
\hline & 6,000 & 100 & 100 & - & 100 & 100 & 100 & 100 & 100 & - \\
\hline & 2,000 & 100 & 100 & 100 & 100 & 100 & 100 & 100 & 100 & 40.2 \\
\hline \multirow{3}{*}{$\begin{array}{l}\text { fenpropathrin } \\
10 \% \text { EC }\end{array}$} & 9000 & - & - & - & - & 80.2 & - & 87.1 & 91.1 & 98.1 \\
\hline & 3000 & 100 & - & - & 100 & 100 & - & 100 & 100 & 96.6 \\
\hline & 1000 & 100 & 100 & 100 & 100 & 100 & - & 100 & 100 & - \\
\hline \multirow{3}{*}{$\begin{array}{l}\text { pyridaben } \\
20 \% \mathrm{WP}\end{array}$} & 27,000 & - & - & - & - & 100 & - & 100 & - & - \\
\hline & 9,000 & - & - & - & - & 100 & - & 100 & 100 & 100 \\
\hline & 3,000 & 100 & 100 & 100 & - & 100 & - & 100 & 100 & 100 \\
\hline \multirow{3}{*}{$\begin{array}{l}\text { fenbutatin- } \\
\text { oxide } 25 \% \text { WP }\end{array}$} & 9,000 & - & - & - & - & 85.6 & - & - & - & - \\
\hline & 3,000 & - & - & - & - & 100 & - & - & - & - \\
\hline & 1,000 & 100 & 100 & - & - & 100 & - & - & - & - \\
\hline
\end{tabular}

Date tested

Date collected Stage collected
Sep.'94 Sep.'94 Sep.'94 Aug.'93 Sep.'92 Aug.'93 Aug.'93 Aug.'93 Jun.'93 Aug.'94 Aug.'94 Aug. '94 Oct.'92 Feb.'92 Aug.'93 Aug.'93 Aug.'93 Apr.'93 Adult Adult Adult Egg Egg Adult Adult Adult Egg

a: Total mortality from eggs to larvae (corrected by Abott's formula).

b: See Table 1. 
Table 3. Susceptibility of $P$. citri populations to five acaricides

\begin{tabular}{lccccccccccccc}
\hline & & \multicolumn{10}{c}{ Ovo-larvicidal activity (\%) $^{\mathrm{a}}$} \\
\cline { 3 - 13 } Acaricides & Dilution & \multicolumn{10}{c}{ Populations $^{\mathrm{b}}$ on peach } \\
\cline { 3 - 13 } & & MB & KD-2 & KD-3 & KS-1 & HY & NG & MG-1 & MG-2 & MG-3 & MG-4 & OY \\
\hline dicofol & 9,000 & 95.0 & - & 6.7 & 0 & 12.0 & 20.5 & - & 7.9 & - & - & 60.4 \\
40\% EC & 3,000 & 93.7 & 65.3 & 2.8 & 36.6 & 40.0 & 30.5 & 97.6 & 94.2 & 47.6 & 73.1 & 92.5 \\
& 1,000 & 100 & 100 & 39.8 & 94.7 & 99.2 & 83.9 & 100 & 100 & 100 & 100 & 100 \\
hexythiazox & 18,000 & 100 & 100 & 0 & - & 4.3 & 93.3 & - & - & - & - & 98.4 \\
10\% WP & 6,000 & 100 & 100 & 0 & - & 36.9 & 100 & 48.1 & - & - & 0 & 97.4 \\
& 2,000 & 100 & 100 & 0 & 0 & 25.5 & 100 & 52.8 & 0 & 0 & 11.5 & 98.4 \\
fenpropathrin & 9,000 & 100 & 100 & 0 & 100 & 94.2 & 96.2 & - & 85.2 & 46.7 & - & 95.1 \\
10\% EC & 3,000 & 100 & 100 & 75.0 & 100 & 100 & 100 & 100 & 100 & 100 & 100 & 99.5 \\
& 1,000 & 100 & 100 & 100 & 100 & 100 & - & 100 & 100 & 100 & 100 & 100 \\
pyridaben & 27,000 & 100 & - & 100 & 100 & 100 & 100 & - & 100 & - & - & 100 \\
20\% WP & 9,000 & 100 & 100 & 100 & 100 & 100 & 100 & - & 100 & 100 & - & 100 \\
& 3,000 & 100 & 100 & 100 & 100 & 100 & 100 & - & 100 & 100 & - & 100 \\
fenbutatin- & 9,000 & 100 & - & - & - & - & - & - & - & - & - & - \\
oxide 25\% WP & 3,000 & 100 & - & - & - & 33.8 & - & - & - & - & - & - \\
& 1,000 & 100 & - & - & 0 & 47.7 & - & - & 0 & - & - & -
\end{tabular}

Date tested Sep.'93 Sep.'93 Oct.'93 Sep.'94 Sep.'94 Oct.'92 Aug. '93 Sep.'94 Aug. '93 Aug. '93 Aug.' '93 Date collected Aug. '93 Sep.'93 Sep. '93 Aug. '94 Aug.'94 Sep.'92 Aug.'93 Aug.'94 Aug.'93 Aug.'93 Aug.'93 Stage collected Adult Adult Adult Adult Adult Adult Adult Adult Adult Adult Adult

a: Total mortality from eggs to larvae (corrected by Abott's formula).

b: See Table 1.

HY, MG-1, MG-2, MG-3, MG-4 の 7 個体群で顕著な感受性低下が認められ，このうち KS1, HY, MG-2 の 3 個体群では, fenbutatin-oxide に対しても著しい感受性低下が認められ た。また, 山陽町神田 (KD-2) と倉敷市道口（MG-1）の 2 園では, 同一園に発生した両種 の個体群の感受性を比較できたが， MG-1では両種間に hexythiazox に対する感受性にお いて明瞭な差が認められた。このようにモモで発生した個体群でみる限り, 薬剤感受性の低 下はクワオオ八ダニでは全く認められず，ミカンハダニでは多くの個体群で認められること が明らかとなった。

\section{考察}

本調查結果から，岡山県下のモモにおいてはクワオオ八ダニとミカンハダニの両種が広く 分布し, 両種の地理的分布の重なりが比較的広い範囲に及んでいることが明らかとなった。 この理由としては, 本来落葉果樹では越冬できないミカン八ダニが，かなり高緯度であって あカンキッなどの常緑樹では越冬可能で, 春〜秋には落葉果樹に侵入して個体群を一時的に 形成することが可能であるためと考えられる。ただし, ミカン八ダニの落葉果樹での発生域 は，現在までのところ正確には捉えられておらず，どの程度の高緯度地域にまでミカン八夕゙ 二がクワオオ八ダニと混在しうるかについては今後の詳細な調查が求められる。

本調査結果はまた, 両種混在地域内では, クワオオ八ダ二の発生量が園ごとに大きく異なる が園ごとには安定し， かつミカン八ダニの発生が多い園で少なくなる傾向があることを明らか にした。この事実は, 両種混在地域ではクワオオ八ダニの発生量がミカン八ダニの侵入による 影響を受けている可能性を示唆するものと考えられる。ミカン八ダニの落葉果樹への侵入がク 
ワオオ八ダニの発生量に影響を与えるメカニズムとしては，すでに野外条件下であ確認されて いるように両種間で起こる種間交雑に基づく生殖干渉の効果を考えることができる（高藤, 1986; Takafuji, 1988; Fujimoto et al., 投稿中)。生殖干渉のクワオオ八ダニへの影響は, ミカ ンハダニのクワオオ八ダニに対する相対的な発生密度が高いほじ強くなる (Fujimoto et al., 投稿中)。そして, ミカン八ダ二の相対密度はミカン八ダ二の侵入時期と侵入量に依存するが, それらは各園ごとに異なる周辺環境に大きく左右される（国本ら，1993)。このような事実と照 らし合わせるならば, 本調查結果は間接的ながら, 両種混在地域において両種間の生殖干渉が クワオオ八ダニの発生量を規定する主要因として働いていることを支持すると考えられる。

本研究では, 発生分布調査に併せて各個体群の薬剤感受性も調べた。クワオオ八ダニでは 感受性の低下は認められなかったが，ミカン八ダニでは特に hexythiazox に対する感受性 において個体群間で大きな変異が認められた。落葉果樹においてはクワオオ八ダニが個体群 を周年維持するのに対し, ミカン八ダニは一時的に発生するだけである。従って, ミカン八 ダニにおいて認められた感受性の低下を落葉果樹における薬剤散布による淘汰の結果とみる よりも, 落葉果樹への侵入前の寄主での淘汰の結果とみる方が妥当であるように思われる。 ミカンハダニの侵入前の寄主としては，これまでにミカンやイヌッゲが報告されている (Takafuji and Morimoro, 1983; Takafuji and Fujimoto, 1986; 孫ら, 1988; 国本ら, 1993)。 そして, ミカン简生のミカンハダニではこれらの供試薬剤に対する感受性低下が報告されて いる（古橋, 1994)。従って, 仮にミカンを侵入源とすれば, モモ寄生のミカン八ダニにおけ る感受性の低下はミカンでの感受性低下が反映された結果とみることができる。しかし，今 回感受性の低下を認めた個体群が発生した園のうち, 山陽町神田 (KD), 岡山市東山 (HY), 倉敷市道口（MG）にある園では近接地でミカンが栽培されていたが, 山陽町鴨前（KS）で は周辺にミカンの栽培を認めなかった。また山陽町神田では, 数本程度のミカン樹からとも に数百 $\mathrm{m}$ 離れていたにもかかわらず，近接する 2 園間でミカンハダニの hexythiazox に対 する感受性が大きく異なった。そしてこの 2 園のうち, 感受性低下が認められた園（KD-3） では薬剤散布が年間 10 回程度, あう一方の園 (KD-2) では 2 3 回程度行われていた。現段 階では, ミカン八ダニがモモに侵入する前の寄主が何であるのか, またモモで発生したミカ ンハダニの感受性低下がどのような過程で起こったかは明らかにはならず，今後実用上の防 除の問題ともからめて詳しく調べる必要があろう。ミカン八ダニがどのような過程で感受性 を低下させたにせよ, 低感受性個体群が感受性個体群よりもモモでの定着およびその後の増 殖が有利となることは当然である。その結果, クワオオ八ダ二と混在する場合に, 生殖干渉 によるクワオオ八ダニへの増殖抑制効果を一層強め, クワオオ八ダ二の発生量を低下させた と考えることができる。クワオオ八ダ二の薬剤感受性が高いことから, 低感受性のミカン八 ダニが発生した園でのクワオオ八ダニの少発を単なる薬剤防除の結果とあ解釈できる。しか し, 岡山市芳賀 (HG) のようにモモの主要産地で薬剤防除が頻繁になされている地域におい てもクワオオ八ダ二のみが認められる園ではその発生密度は高かった。また，大藪 (OY) の ようにミカン園と隣り合っているモモ園では, 感受性の高いミカン八ダニが多発しているに あかかわらず, クワオオ八ダ二の発生が認められなかった。これらの事実から, 薬剂散布の 影響だけによって両種の発生の有無が決定されるのではなく, 薬剤散布によって両種間の生 殖干涉の度合が変化し, 両種の発生分布が変化していくものと推察される。ただし，この推 察を証明するには本結果だけでは不十分であり, 両種が混発する園をいくつかのブロックに 区切り，ブロックごとに薬剤防除体系を変えたり，人為的にミカンハダ二の侵入量を変える などして両種の発生量を長期にわたって調べ, 実際にクワオオ八ダニの発生量がブロックご とに異なっていくかどうかを明らかにする必要があろう。 
摘

要

岡山県下のモモにおけるクワオオ八ダニとミカンハダニの発生状況を 1992 年から 1994 年 にかけて調べた。また併せて, 各地から得られた両種それぞれの個体群について主要殺ダニ 剂に対する感受性を調べた。

1. 両種ともに岡山県下のモモに広く分布し, 両種の地理的分布の重なりが岡山県中南部 を中心とした比較的広い範囲に及んでいることが明らかとなった。

2. 両種混在地域内においては, クワオオ八ダニの休眠卵量はミカン八ダニの多発が認め られた園で少ない傾向を示した。

3.クワオオ八ダニはいずれの個体群も供試した 5 薬剤 (dicofol, hexythiazox, fenbutatin-oxide, fenpropathrin, pyridaben）に対して高い薬剤感受性を示したが, ミカン八 ダニは幾つかの個体群が hexythiazox, fenbutatin-oxide に対して顕著な感受性低下を 示した。

\section{引用文献}

Ehara, S. and T. Gotoh (1992): Descriptions of two Panonychus spider mites from Japan, with a key to species of the genus in the world (Acari: Tetranychidae) Appl. Entomol. Zool., 27: 107-115.

古橋嘉一 (1994)：静岡県におけるミカン八ダ二の薬剤感受性. 関東病虫研報, 41: 267-269.

岩田俊一・守谷茂雄・大竹昭郎・斉藤哲夫・清水信義・真梶徳純・梅谷献二（編）(1984)：ミカン八ダ 二の殺だに剤抵抗性に関する研究. 104 p., 日本植物防疫協会, 東京.

国本佳範・真梶徳純・天野 洋 (1993)：イヌッゲに寄生するミカンハダニのナシ園への侵入. 応動昆, 37: 69-73.

刑部正博 (1985)： $\alpha$-および $\beta$-naphthyl acetate を加水分解するミカン八ダニの非特異的エステラーゼ の性質. 応動昆, 29: 50-54.

Osakabe, Mh. (1987): Difference of esterase isozymes between non-diapausing and diapausing strains of the citrus red mite, Panonychus citri (McGregor) (Acarina:Tetranychidae) Appl. Entomol. Zool., 22: 577-584.

真梶徳純（1961）：主要果樹に寄生するミカンハダニの地理的分布. 東近農試研報（園芸)，6: 49-63.

Shinkaji, N. (1979): Geographical distribution of the citrus red mite, Panonychu citri and European red spider mite, P. ulmi in Japan. Recent Adv. Acarol., 1: 81-87.

真梶徳純・三田 毅・天野 洋・福田 寛・藤家 梓 (1986): 千葉県のナシにおけるミカン八ダニの休 眠性系統之非休眠性系統の地理的分布．関東病虫研会報，3: 219-220.

孫 緒良・真梶徳純・天野 洋 (1988): 千葉県北部のナシに招ける休眠性と非休眠性ミカン八ダ二の発 生経過. 応動昆 32: 260-265.

高藤晃雄 (1986): ミカン八ダ二の系統間の生殖隔離. 植物防疫, 40: 433-438.

Takafuji, A. (1988): Mating between diapausing and nondiapausing strains of the citrus red mite, Panonychus citri (McGregor). Mem. Ent. Soc. Can., 146: 131-189.

Takafuji, A. and H. Fujimoto (1986): Winter survival of the non-diapausing population of the citrus red mite, Panonychus citri (McGregor) (Acarina: Tetranychidae) on pear and citrus. Appl. Entomol. Zool. 21: 467-473.

Takafuji, A. and N. Morimoto (1983): Diapausing attributes and seasonal occurences of two populations of the citrus red mite, Panonychus citri (McGregor) on pear (Acarina: Tetranychidae). Appl. Entomol. Zool., 18: 525-532.

山田健一・野田正春 (1985)：福岡県におけるナシの休眠性ミカンハダニの初発生と発生生態について. 福岡農総試研報, B 5: 35-38. 